\title{
Kategoria jednoznaczności i wieloznaczności przekazu muzycznego w świetle koncepcji dzieła otwartego Umberto Eco
}

Damian Binkowski | Wydział Filologiczny, Uniwersytet Gdański

Słowa kluczowe:

estetyka korespondencja

sztuk,

dzieło otwarte,

percepcja

wieloznaczność

\section{Streszczenie}

Wśród dzieł zakwalifikowanych przez Umberto Eco jako otwarte szczególne miejsce zajmują wytwory artystyczne reprezentujące sposób istnienia łączony przez niego z kategorią otwarcia drugiego stopnia, zarezerwowaną dla dzieł fizycznie domkniętych, które zostały zdefiniowane przez włoskiego semiotyka jako źródła przekazów o strukturze wieloznacznej.

W niniejszych rozważaniach podjęto próbę określenia cech takich utworów na podstawie przesłanek zawartych w Dziele otwartym Eco, uwzględniając istnienie stosunku percepcyjnego dzieło-odbiorca determinowanego przez właściwości strukturalne przekazu artystycznego. Dzięki temu możliwe stało się określenie, jakie czynniki sprzyjają wzmocnieniu jednoznaczności przekazu muzycznego, a tym samym - na zasadzie przeciwieństwa w stosunku do niejopis okoliczności prowadzących do zwiększenia jego wieloznaczności.

\section{Category of ambiguity of the musical message in the light of Umberto Eco's open work concept}

\section{Abstract}

Keywords:

aesthetics, correspondence of arts, open work, perception ambiguity

Among the works classified by Umberto Eco as open, a special place is taken by the artistic works representing the way of existence connected with the category of the openness of the second degree, reserved for physically closed works. Such works were defi nedby the Italian semiotician as sources of transmissions of ambiguous structure.

In the article, attempts were made to determine the characteristics of such works on the basis of the propositions from Eco's Open Work, taking into account the existence of the perceptual work-recipient relationship determined by the structural properties of the artistic transmission. Thereby, it became possible to determine what factors foster the unambiguity of the musical message and, by means of contrast, the description of circumstances leading to its increased ambiguity. 
Umberto Eco wyróżnił trzy typy wytworów artystycznych zasługujących na miano otwartych. Zdecydowana większość z kompozycji muzycznych przywołanych na kartach Dzieła otwartego została zakwalifikowana przez niego jako reprezentująca pierwszy z nich, do którego należą tak zwane dzieła w ruchu. Eco nie przytoczył jednak żadnego tytułu utworu muzycznego, jaki mógłby spełniać warunki otwarcia pierwszego stopnia, definiującego drugi typ tego rodzaju dzieł. Podobną postawę autor Imienia Róży zajął wobec otwarcia drugiego stopnia, a więc otwarcia trzeciego typu. Co prawda, zasygnalizował możliwość jego zaistnienia w muzyce, nie podając konkretnych przykładów dzieł posiadających takie właściwości, a dostarczając jedynie kontrprzykładu zaczerpniętego z Menuetu g-moll (BWV 115) Johanna Sebastiana Bacha z Notenbüchlein für Anna Magdalena Bach, zawierającego struktury dźwiękowe określone przez Eco jako jednoznaczne (por. Eco 1994: 177). Celem dzieł opisywanych przez kategorię otwarcia drugiego stopnia jest bowiem dostarczenie "przekazów o strukturze wieloznacznej” (Eco 2008: 153). Wątek ten zostanie podjęty i rozwinięty w niniejszych rozważaniach, stawiających sobie za cel określenie, które czynniki sprzyjają wzmocnieniu jednoznaczności przekazu muzycznego, a tym samym wskazanie - na zasadzie przeciwieństwa w stosunku do niej - okoliczności prowadzących do zwiększenia wieloznaczności ukształtowań dźwiękowych. Nie ma to jednak nic wspólnego z zagadnieniem tak zwanych topoi muzycznych, odnoszonych do określonych figur muzyczno-retorycznych, funkcjonujących w ramach paradygmatu wspólnego dla muzyki barokowej, klasycznej i wczesnoromantycznej, wywodzącego się z renesansowej idei imitazione della natura, a tym bardziej z problemem obecności treści literackich w muzyce programowej (por. Mianowski 2004: 31-32). Rozważania podejmowane w kontekście koncepcji otwarcia drugiego stopnia stworzonej przez Eco uwzględnić muszą przede wszystkim stosunek percepcyjny dzieło-odbiorca uwarunkowany przekazem muzycznym, skupiając się na jego właściwościach strukturalnych i materiałowych (por. Eco 1994: 21). Próbując zdefiniować tę relację, Eco odwołał się między innymi do pojęcia redundancji, zaczerpniętego z teorii informacji, adekwatnego do opisu zjawisk językowych, ale też muzycznych, biorąc pod uwagę istnienie między nimi analogii zasugerowanych przez niego. Pojęcie to wymaga szerszego przedstawienia, jednak wcześniej warto bardziej szczegółowo scharakteryzować dzieła odniesione przez włoskiego semiotyka do każdej z trzech wyróżnionych wyżej kategorii i w ten sposób ukazać specyfikę sposobu istnienia łączonego tylko $z$ jedną $z$ nich.

Do dzieł w ruchu Eco zaliczył między innymi: słynną Księgę Stéphane’a Mallarmégo, ruchome rzeźby (mobile) Alexandra Caldera, budynek Wydziału Architektury Uniwersytetu w Caracas w Wenezueli, wybrane dzieła sztuki użytkowej oraz postwebernowskie kompozycje muzyczne z lat pięćdziesiątych ubiegłego wieku, jak: III Sonata fortepianowa Pierre'a Bouleza, Klavierstück XI Karlheinza Stockhausena czy Scambi Henriego Pousseura. Między twórcą i interpretatorem dzieła w ruchu ustanowiona zostaje relacja, w której zacierają się granice pomiędzy polami aktywności każdego z nich. Artysta z własnej woli zrzeka się wówczas odpowiedzialności za kształtowanie 
formy swojego utworu na rzecz wykonawcy lub odbiorcy. Dochodzi między nimi do współpracy bezpośredniej, ingerującej w materialną postać przedmiotu artystycznego. Umożliwia to wewnętrzna mobilność tego rodzaju form, sprawiająca, że układ elementów tworzących ich strukturę nie jest już zdeterminowany. Dzieła w ruchu są bowiem fizycznie nieukończone - są zatem dziełami otwartymi sensu stricto (por. Eco 1994: 23-56).

Wspomniana Księga autorstwa Mallarmégo miała składać się z zeszytów zawierających oddzielne kartki z tekstem. Francuski pisarz zakładał możliwość dowolnego przestawiania ich i zestawiania, zachowującego sens niezależnie od kolejności, w jakiej zostały ułożone przez czytelnika. Rzeźby Alexandra Caldera - nie bez powodu określane jako mobile - również posiadają zdolność przekształcania swej postaci. Ruchome są również płyty, z których zbudowano pomieszczenia zajmowane przez Wydział Architektury Uniwersytetu w Caracas, dzięki czemu wewnętrzna struktura budynku uczelni może być nieustannie modyfikowana dla celów edukacyjnych. Podobne właściwości wykazują zarówno projektowane współcześnie składane fotele i lampy, jak i meblościanki złożone z segmentów dających się przestawiać i zestawiać na rozmaite sposoby. Z kolei w III Sonacie fortepianowej Bouleza mobilność strukturalną wykazuje zwłaszcza jej część inicjalna, zanotowana na dziesięciu kartkach tak, by pianista mógł nimi manipulować jak fiszkami, samodzielnie ustalając kolejność następstwa poszczególnych odcinków utworu. Tego samego wymaga od niego Klavierstück XI Stockhausena, gdzie dodatkowo może zadecydować o tym, które z dziewiętnastu grup dźwiękowych, zapisanych nieregularnie na arkuszu papieru, zostaną przez niego powtórzone, a które pominięte. Strukturę kombinatoryczną posiada też Scambi - utwór elektroniczny określony przez Pousseura jako "nie tyle utwór, co pole możliwości, zaproszenie do wyboru" (Eco 1994: 23). Realizator Scambima do dyspozycji szesnaście fragmentów muzycznych, które może zestawiać na rozmaite sposoby, zarówno sukcesywnie, jak i symultanicznie. Żadna z tych kompozycji nie jest zatem zdeterminowana w odniesieniu do wykonania, a każda realizacja nadaje im unikatową formę, czy też - jak określił ją John Cage - morfologię ciągłości (Cage 2010: 228). Forma tego typu utworów jest zmienna, mimo że w szczegółach nadal zdeterminowana (Paja-Stach 1992: 27). W przypadku Scambi Eco uwzględnił też możliwość udziału słuchacza w procesie kształtowania przebiegu utworu muzycznego pod warunkiem zastosowania urządzenia, które pozwoliłoby odbiorcy na samodzielny, zgodny z jego indywidualną wrażliwością, montaż ruchomych elementów strukturalnych kompozycji, nagranych wcześniej na taśmie magnetycznej (por. Eco 1994: 24).

Drugi i trzeci typ otwarcia reprezentują dzieła zachowujące sztywną strukturę, a więc ukończone i fizycznie domknięte. Charakterystyczna dla nich jest konieczność intelektualnego i percepcyjnego zaangażowania się odbiorcy, łączonego przez Eco z koncepcją poznania sformułowaną przez psychologów transakcyjnych. Zgodnie z założeniami owej koncepcji postrzegania nie należy sprowadzać do biernej recepcji rzeczywistości oraz elementów składających się na nią, jakie mogłyby znaleźć 
w podmiocie swoje odbicie. Każdy akt percepcyjny okazuje się zjawiskiem otwartym na interwencje psychiczne podmiotu, reagującego i jednocześnie oddziałującego na bodźce docierające do niego, zapośredniczone przez narządy zmysłów, ale też - przez strukturę wspomnień doświadczeń percepcyjnych nabytych wcześniej, która jest cechą indywidualną jaźni każdego człowieka (Eco 2008: 166-168, 171). Te same bodźce wzbudzać mogą różne reakcje - sposób, w jaki zostaną zinterpretowane, determinują osobiste dyspozycje jednostki. Postrzeganie jest zatem „procesem otwartym na wiele rozwiązań" (Eco 2008: 170). W procesie transakcji psychologicznej własne schematy poznawcze, ukształtowane przez wcześniejsze akty percepcyjne, projektowane są przez odbiorcę wrażeń na bliżej nieokreślone pole bodźców (bo takim okazuje się ono dla podmiotu), co pozwala mu na podjęcie aktywności konstrukcyjnej zmierzającej do zasymilowania przedmiotu przezeń percypowanego. Granice istniejące pomiędzy podmiotem i przedmiotem (a więc również - jak to miało miejsce w przypadku dzieł w ruchu - pomiędzy polami aktywności odbiorcy i twórcy dzieła sztuki) zacierają się, a liczba interpretacji danej konfiguracji bodźców może być nieskończona (Eco 2008: 169, 183; Binkowski 2016: 254). Albowiem - jak zakładają psycholodzy transakcyjni - „podmiot nie jest zdeterminowany przez przedmiot” (Eco 2008: 171).

Zdaniem Eco model postrzegania rzeczywistości wyłaniający się z tych założeń dotyczy każdego dzieła sztuki i każdego udanego doświadczenia estetycznego, co starał się opisać przy pomocy kategorii otwarcia pierwszego stopnia, łączonej przez niego zwłaszcza z sytuacjami, w których ważną rolę odgrywa bagaż kulturowy stanowiący istotną część wyposażenia poznawczego jednostki ludzkiej, wzbogacany przez jej kolejne percepcje estetyczne. Do otwarcia pierwszego stopnia dochodzi między innymi w tradycyjnie rozumianej poezji, albowiem znak językowy jest również polem bodźców, użytym w języku poetyckim estetycznie. Eco podzielił przy tym przebieg procesu odbioru dzieł wierszowanych na kolejne fazy. Największą rolę odgrywają tu faza pierwsza i druga, wyzwalające reakcję łańcuchową, teoretycznie nieskończoną, złożoną z faz następnych, składających się na doświadczenie formy wytworu artystycznego (por. Eco 1994: 77-81). Estetyczna organizacja bodźców wyklucza jednakże możliwość wyłącznie referencyjnego odczytywania znaczeń denotowanych przez wyrażenia stanowiące treść wiersza, dlatego w pierwszej fazie ich postrzegania:

[...] znaki łączą się wedle nawyków zakorzenionych we wrażliwości odbiorcy (które, choć nazywamy je gustem, są rodzajem kodu, historycznie usystematyzowanego). A więc bodźce, połączone przez rym, metrum, skonwencjonalizowane proporcje, przez ustalone odniesienie do tego, co realne, co prawdopodobne, co „zgodne z przyjętą opinią" albo „odpowiadające zwyczajom stylistycznym" - tworzą w sumie swoistą nierozerwalną całość, której odbiorca nie może dzielić. Nie wolno mu izolować poszczególnych związków, musi uchwycić w całości przesłanie, jakie mu przekazuje dane wyrażenie. Ale to sprawia, że jego sens jest nie jednoznaczny, lecz wieloznaczny i właśnie z tej racji pierwsza faza procesu poznawczego budzi w nas zarówno pewien rodzaj zadowolenia, jak i niedosytu (Eco 1994: 79). 
Wieloznaczność przekazu poetyckiego przyswojonego w pierwszej fazie odbioru wiersza przywołuje wspomnienia doświadczeń przeszłych i stwarza przestrzeń dla ich projekcji:

Druga faza odbioru obejmie zatem owe reminiscencje, które będą współdziałać ze znaczeniami wyłonionymi w drugim kontakcie. Te zaś będą się różnić od znaczeń powstałych w wyniku pierwszego kontaktu, gdyż złożoność bodźca estetycznego sprawia, że ten ponowny odbiór dokonuje się z innej perspektywy, według nowej hierarchii bodźców. Zwracając ponownie naszą uwagę na zespół bodźców, wydobędziemy na pierwszy plan te znaki, które uprzednio zauważyliśmy mimochodem, i odwrotnie. W akcie transakcyjnym, który łączy bagaż wcześniejszych doświadczeń i system znaczeń powstałych w drugiej fazie oraz system powstały w pierwszej fazie (przy czym ten ostatni pojawia się jako przypomnienie, jako „echo”), kształtuje się głębsze znaczenie wyrażenia. Im bardziej proces poznania się komplikuje, tym mniej komunikat początkowy - jakikolwiek jest i z czegokolwiek jest zbudowany - zużywa się, tym bardziej się odradza, otwiera na wciąż nowe "lektury" (Eco 1994: 80).

Istnieją jednak dzieła, w których uwzględnienie procesów psychicznych opisywanych przez psychologów transakcyjnych wydaje się zamierzone, które pełnią funkcję epistemologicznej metafory wobec zaproponowanego modelu rzeczywistości. To właśnie dla nich Eco zarezerwował kategorię otwarcia drugiego stopnia (por. Eco 2008: 128, 170-171, 181). W trakcie słuchania muzyki pozwala ono melomanom „odbierać materiał dźwiękowy na rozmaite sposoby", natomiast odbiorcy malarstwa daje do dyspozycji „rozmaite kierunki odczytania obrazu” (Eco 2008: 128). Kategoria otwarcia drugiego stopnia zakłada więc istnienie intencji wielorakiego odbioru treści artystycznych zawartych w samym dziele sztuki. Można tu zatem mówić o fundamentalnej wieloznaczności przekazu artystycznego, uzyskanej dzięki jego zdolności do nieustannego wytwarzania nowych relacji wewnętrznych, otwierającej dzieło na rozmaite interpretacje (Eco 2008: 51, 96, 128). Zrodzone tym samym bogactwo informacyjne zostało określone przez Eco jako wartość mierzona liczbą „możliwych wyborów, dających się wyodrębnić na płaszczyźnie komunikatu oznacznika" (Eco 1994: 120). Eco przeciwstawił tę wartość redundancji: maksymalna informacja oznacza wówczas minimalną redundancję. Informacja określa zatem stopień niedoprecyzowania danego przekazu, natomiast redundancja - pozwala zwiększyć jego jednoznaczność (Eco 2008: 183; Załuski 2000: 75).

Przykładu wprowadzenia redundancji do systemu komunikacyjnego dostarcza sytuacja przywołana przez Eco, w której do stworzenia elementarnego kodu oraz komunikatów zgodnych z jego regułami zostaje wykorzystany obwód elektryczny oraz podłączona do niego lampka wraz z pływakiem unoszącym się na powierzchni wody znajdującej się w zbiorniku retencyjnym. Osiągnięcie przez nią stanu alarmowego powoduje wzniesienie się pływaka na odpowiednią wysokość, a w rezultacie zamknięcie obwodu elektrycznego i zapalenie lampki. Dopóki poziom alarmowy wody nie zostanie przekroczony, dopóty lampka pozostaje zgaszona. Prostota kodu 
stwarza jednak ryzyko podatności całej instalacji na zakłócenia oraz niebezpieczeństwo wprowadzenia do kanału informacyjnego dodatkowych, niepożądanych znaczeń. Obwód elektryczny może być uszkodzony. Istnieje też ryzyko braku dopływu prądu do obwodu z zewnątrz. W obu wypadkach lampka nie zapali się, co wcale nie musi oznaczać, że poziom wody w zbiorniku nie osiągnął jeszcze stanu alarmowego (por. Eco 1994: 92). By więc zachować jednoznaczność przekazu i uchronić go przed zniekształceniami (w omawianym przykładzie są one rezultatem braku dopływu prądu do lampki spowodowanym przez różne czynniki), Eco zaleca wprowadzenie do kodu elementów redundancji przez podwojenie komunikatu - na przykład przez podłączenie do tej samej instalacji elektrycznej drugiej lampki, która zapalałaby się tylko wtedy, gdy lampka używana dotąd jest wyłączona, wskazując stan wody niższy od alarmowego. Pomimo zwiększenia stopnia skomplikowania przyjęty kod nie uwzględnia sytuacji, w której obie lampki świecą lub obie są zgaszone, co może świadczyć o awarii instalacji, w każdym razie pozwala odróżnić znaczenia oczekiwane od niepożądanych. Okazuje się jednak, że w celu uniknięcia usterki mogącej spowodować zapalenie się lampki pierwszej - zamiast drugiej - lub odwrotnie korzystne byłoby ponowne wprowadzenie redundancji przez podwojenie komunikatu już raz podwojonego, a w rezultacie - wykorzystanie czterech lampek zamiast dwóch. Zapalenie pierwszej i trzeciej lampki wskazywałoby wówczas, że w zbiorniku retencyjnym zachowany zostaje bezpieczny poziom wody, natomiast zagaszenie ich i zapalenie w zamian lampek: drugiej i czwartej świadczyłoby o przekroczeniu tego poziomu (por. Eco 1994: 92-93).

Każdy naddatek treści służący jej wzmocnieniu, a przez to zwiększeniu skuteczności komunikacyjnej, zasługuje na miano redundancji, występującej również w języku - przede wszystkim jako pochodna podstawowych zasad: ortograficznych, gramatycznych czy syntaktycznych, określających jego reguły jako kodu. Dzięki nim dochodzi do wprowadzenia, potwierdzenia oraz utrwalenia ładu językowego, ustanawiającego relacje (również logiczne), których stopień dookreślenia pozwala na przykład odgadnąć, jaki wyraz wystąpi w danym fragmencie tekstu, oraz sprecyzować formę tego wyrazu na podstawie jego kontekstu. To, co pojawia się wcześniej, pozwala czytelnikowi przewidzieć to, co nastąpi później i dokończyć zdanie: „Dziś mija kolejna rocznica katastrofy smoleńskiej, od której minęło już siedem ..." (por. Popławski 2004: 246). Do obecności redundancji w języku przyczynia się też interpunkcja. Jej działanie jest z kolei wzmacniane przez przyjęte konwencje zapisu - na przykład tę, która nakazuje, by po postawieniu kropki kończącej zdanie rozpocząć zdanie następne wielką literą, co też prowadzi do powstania pewnego nadmiaru i jest działaniem dodatkowym, wzmacniającym znaczenie samej kropki jako znaku interpunkcyjnego. Na poziomie bardziej elementarnym czynnikiem zwiększającym stopień redundancji komunikatu językowego jest obecność samogłosek, wzmacniających jednoznaczność słów i potwierdzających ich znaczenie, które możliwe jest do odczytania już na podstawie spółgłosek wchodzących w ich skład (Eco 2008: 137-139). Precyzja języko-

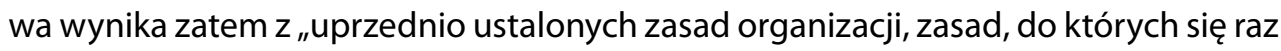


po raz odwołujemy na skutek powtarzania się dających się przewidzieć elementów" (Eco 1994: 175).

Do wprowadzenia elementu redundancji do komunikacji językowej dochodzi również w sytuacji, gdy funkcjonariusz policji, przekazując za pomocą krótkofalówki informacje dotyczące wylegitymowanej przez siebie osoby, literuje jej imię, nazwisko i adres, by uniknąć pomyłki po stronie centrali, jaką mogłyby spowodować zarówno zakłócenia występujące w połączeniu radiowym, jak i wada wymowy policjanta. Redundancja zostanie zwiększona, gdy czynności literowania towarzyszyć będzie wypowiadanie wyrazów rozpoczynających się kolejnymi głoskami, wchodzącymi w skład słów zawartych w przekazywanych przez policjanta danych osobowych (np. „a jak Anna, b jak Barbara, itd."). Uzyskany w ten sposób stopień redundancji może być podniesiony przez dokładne określenie, jakie słowo odpowiada danej literze (wystarczające jest wówczas wypowiedzenie tylko tego słowa, np.: „Alpha, Bravo, Charlie, itd."), jak to ma miejsce w wypadku alfabetu fonetycznego ICAO, opracowanego w latach pięćdziesiątych ubiegłego wieku przez Organizację Międzynarodowego Lotnictwa Cywilnego i przejętego później przez NATO. Alfabet ICAO tworzy system, w którym wysoki stopień redundancji podniesiono jeszcze bardziej dzięki ustaleniu zasady, zgodnie z którą w żadnym z dowolnie wybranych dwóch i więcej słów występujących w tym alfabecie nie może wystąpić taka sama sylaba. Dzięki temu możliwe stało się jednoznaczne zrozumienie komunikatu nawet wtedy, gdy do odbiorcy docierają tylko jego fragmenty.

Eco zwrócił uwagę na urzeczywistnienie ładu, do jakiego dochodzi w muzyce opartej na systemie dur-moll, gdzie precyzyjny kształt oraz jednoznaczność harmoniczna układów dźwiękowych i relacji zachodzących pomiędzy nimi są pochodną redundancji wypływającej przede wszystkim z zasad gramatyki tonalnej, tworzącej układ odniesień i sprecyzowanych stosunków, implikujący następstwa współbrzmień, które - tak jak to miało miejsce w przypadku języka - można odtworzyć na podstawie ich kontekstu. Jednak - jak zauważa Witold Rudziński - jednoznaczność ukształtowań muzycznych podkreślana jest nie tylko przez tonację oraz sposób opracowania harmonicznego danego przebiegu dźwiękowego, ale też przez czynnik metro-rytmiczny, jak dzieje się w przywołanym przez niego Preludium A-dur op. 27 nr 7 Fryderyka Chopina (rys. 1), zawierającym muzyczne odpowiedniki wizualnych układów spoistych jednoznacznych, nazywanych przez gestaltystów formami dobrymi (por. Rudziński 1987: 131).

Do podniesienia poziomu redundancji przyczynia się tu również faktura homofoniczna oraz budowa okresowa dzieła. Skontrastowanie melodii (figura) względem akordowego akompaniamentu (tło) nadaje jej funkcję pierwszoplanową i konstytuuje ją jako odrębną całość. Ze względu na swą wyrazistość melodia zachowuje jednolitość nawet wtedy, gdy zostanie transponowana do innej tonacji. Z kolei budowa okresowa kompozycji muzycznej, syntetyzując i silnie integrując jej elementy składowe w jasno określonym, symetrycznym porządku taktowym, pozwala stworzyć zamknięte ukształtowania dźwiękowe zakończone kadencją, traktowaną jako rodzaj 

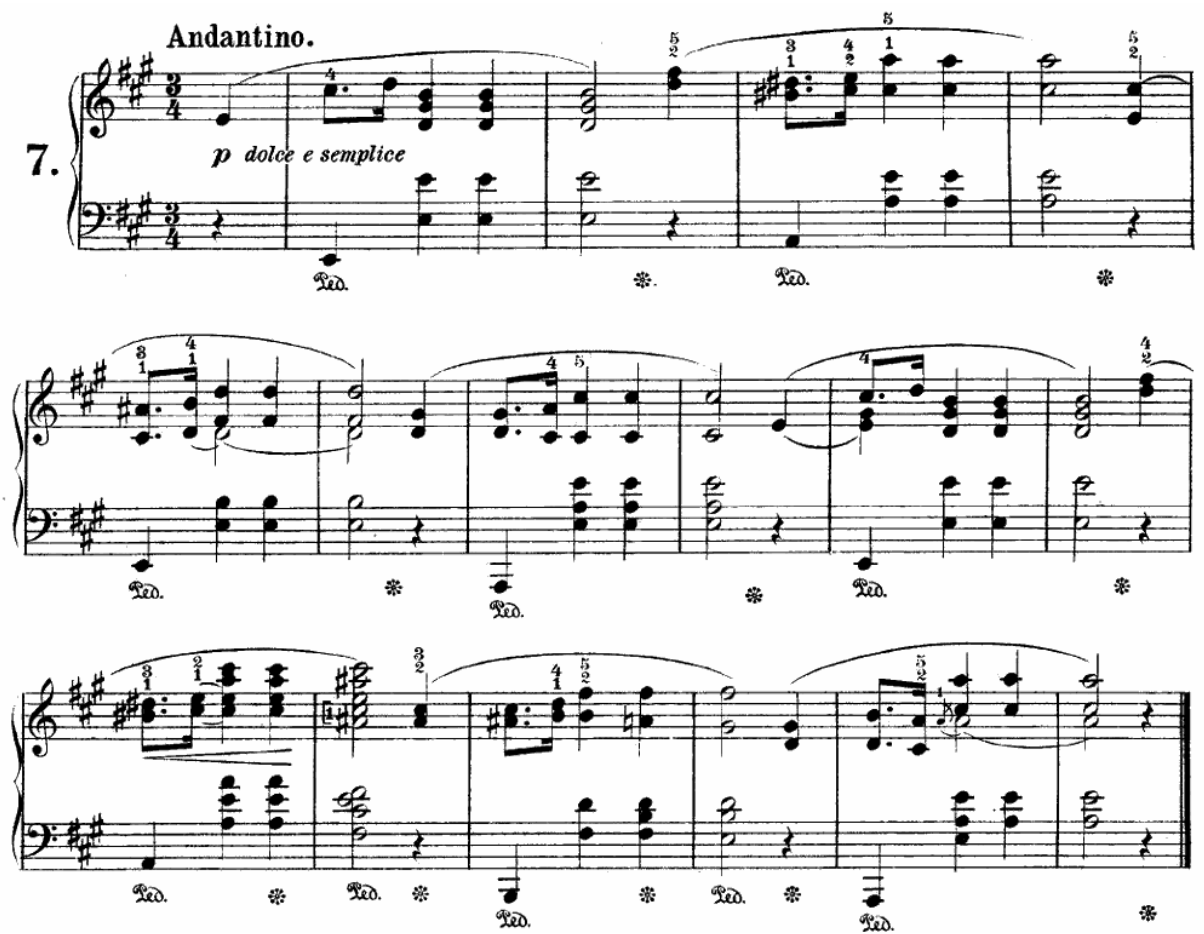

Rys. 1. Fryderyk Chopin, Preludium A-dur, op. 27, nr 7

Źródło: http://pl.cantorion.org/music/133/Prelude-No.-7-Original-version [dostęp: 1.11.2017].

znaku interpunkcyjnego. Konstrukcja tego rodzaju, złożona z segmentów o jasno zarysowanych cezurach, również jest zorganizowana w sposób hierarchiczny. Dodatkowy kontrast wprowadza relacja zachodząca pomiędzy poprzednikiem i następnikiem, wytwarzająca polaryzację energetyczno-tonalną (por. Demska-Trębacz 2005: 99, 123-129).

Formy dobre - jak twierdził Eco - uzyskuje się zatem przez wprowadzenie maksymalnej redundancji (minimalnej informacji), co w wypadku Preludium A-dur Chopina oznacza również wprowadzenie hierarchii strukturalnej, będącej skutkiem uwypuklenia czy też doprecyzowania kształtu danego przebiegu dźwiękowego przez uczynienie go elementem nadrzędnym, podstawowym, istotnym (figura), dominującym nad pozostałymi elementami tworzącymi wraz z nim pewną konfigurację, które tym samym zyskują status elementów podrzędnych (tło) (Eco 1994: 154; Rudziński 1987: 127). Tego samego nie można jednak powiedzieć o tak zwanych niejednoznacznych układach spoistych (dwoistych, troistych, wieloznacznych), pozwalających przyjąć wobec siebie więcej niż jeden punkt widzenia, co - zdaniem Eco - jest możliwe właśnie dzięki opisanej przez psychologów transakcyjnych zdolności podmiotu do dokonywania percepcyjnych modyfikacji i korektur w informacjach niesionych przez bodźce dostarczane przez zmysły (Eco 2008: 170). Efekt niejednoznaczności osiąga się przede wszystkim przez zrównoważenie relacji zachodzących pomiędzy figurą i tłem, utrzymywanych 
w stanie nierozwiązywalnego napięcia. W tego rodzaju układach żaden z elementów nie dominuje nad pozostałymi, tak jak biała waza ze słynnego rysunku z podręczników do psychologii nie dominuje nad dwiema czarnymi twarzami widzianymi z profilu (i vice versa), tworzącymi wraz z nią dwuznaczny układ nieodwracalny.

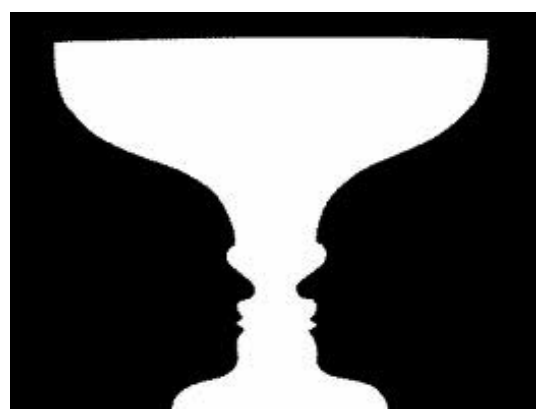

Rys. 2. Niejednoznaczny układ spoisty

Źródło: http://mathworld.wolfram.com/ Gobletlllusion.html [dostęp: 1.11.2017].

Rysunek 2 może być interpretowany dwojako, wymagając od osoby przyglądającej się mu przyjęcia dwóch trybów postrzegania, wykluczających się nawzajem i występujących naprzemiennie. Zarówno waza, jak i twarze posiadają cechy figury i tła (por. Rudziński 1987: 127-129). O funkcji, jaką będą pełnić, zadecyduje odbiorca posiadający swobodę wyboru aspektu obrazu, na którym skupi swoją uwagę.

Rudziński zwraca uwagę na występowanie podobnych zjawisk w muzyce, przywołując pierwsze, jednogłosowe przeprowadzenie tematu fugi z Preludium i fugi a-moll (BWV 543) Johanna Sebastiana Bacha, gdzie po wyraźnie zarysowanym motywie czołowym następuje rozwinięcie tematu złożone wyłącznie z figuracji szesnastkowych. Jednolitość jego przebiegu - utworzonego przez następstwo jednakowych wartości rytmicznych, krótszych o połowę od czasu trwania jednostki metrycznej - niweluje możliwość regularnego akcentowania wybranych impulsów dźwiękowych przez ich wydłużenie, jakie mogłoby dostarczyć wyrazistego punktu odniesienia, zgodnego $z$ tokiem metrycznym. Poczucie tego ostatniego zostaje w ten sposób osłabione. Tym samym powstała chwiejność rytmiczna, będąca rezultatem zrównoważenia pierwotnego poczucia iktusu i jego przesunięcia o wartość szesnastki. Do ustanowienia niejednoznacznej relacji zachodzącej pomiędzy figurą a tłem - analogicznej do stosunku, jaki zachodził pomiędzy białą wazą i dwiema czarnymi twarzami na przywołanym wyżej rysunku - może przyczynić się już czynnik rytmiczny (Rudziński 1987: 131-132).

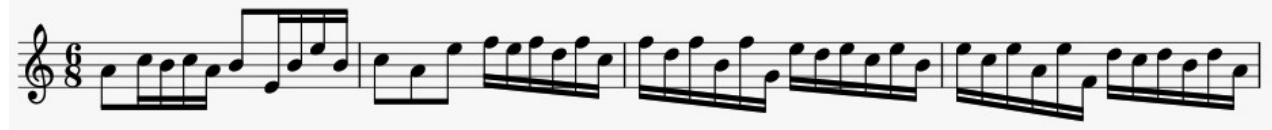

Rys. 3. Temat fugi. Johann Sebastian Bach, Preludium i fugi a-moll (BWV 543) Źródło: Demska-Trębacz M., 2005: 100. 
Eco przypisuje jednak największe znaczenie gramatyce tonalnej, regulującej sposób organizacji układów dźwiękowych występujących w kompozycjach Bacha, albowiem - co potwierdza również Rudziński - już relacje zachodzące pomiędzy stopniami danej skali durowej czy molowej są wystarczająco jasno określone, by stanowić całość wyrazistą i jednoznaczną (Rudziński 1987: 131). Eco uważał, że są one, tak jak wszelkie formy dobre, na tyle precyzyjne i oczywiste, że nie wymagają od odbiorcy podejmowania jakiejkolwiek aktywności interpretacyjnej, przeciwstawiając twórczości lipskiego kantora muzykę serialną Antona Weberna. Przekaz zawarty w utworach austriackiego dodekafonisty jest bowiem na tyle wieloznaczny, że wyklucza uprzywilejowanie wybranych kierunków rozwoju toku dźwiękowego kosztem pozostałych, wywołane ciążeniem wszystkich dźwięków skali ku jednemu centrum tonalnemu (Eco 1994: 178-179; 2008: 165). Podobne właściwości zostały przez Eco przypisane malarstwu informel:

[...] tu rzeczywiście znaki układają się niczym konstelacje, w których związki strukturalne nie są od początku jednoznacznie określone; w których nieokreśloność znaku nie sprowadza się (jak u impresjonistów) ostatecznie do potwierdzenia różnicy między formą i tłem, gdyż samo tło staje się tematem obrazu (temat obrazu staje się zaś tłem jako możliwość ciągłej metamorfozy) (Eco 1994: 163-164).

Eco nie dostarczyłżadnego przykładu utworu Weberna ilustrującego zakładany przez niego stan rzeczy. Można się zatem tylko domyślać, że obniżenie stopnia redundancji przekazu muzycznego zostało utożsamione przez włoskiego semiotyka z wykorzystaniem całego materiału dodekachordalnego oraz z destabilizacją tworzywa dźwiękowego, spowodowaną przez likwidację odniesień funkcyjnych, co w rezultacie pozwoliło zupełnie zniwelować, charakterystyczne dla systemu dur-moll, napięcie istniejące pomiędzy podstawą harmoniczną i warstwą melodyczną kompozycji muzycznej, uwarunkowane przez ciążenia tonalne (por. Gołąb 1987: 18-23, 92). Uzyskana w ten sposób całkowita autonomia i równoważność każdego ze składników skali chromatycznej, a w konsekwencji prymat struktury nad materiałem, doprowadziły do sytuacji, w której niemożliwe okazało się ustanowienie relacji nadrzędności i podrzędności wybranych elementów przebiegu dźwiękowego (a więc jednoznacznego określenia, co pełni w nim funkcję figury, a co tła), co wydaje się być warunkiem powstania stosunku percepcyjnego istniejącego między dziełem i jego odbiorcą łączonego przez Eco z kategorią otwarcia drugiego stopnia, opisującą dzieła, których celem stała się wieloznaczność.

\section{Literatura}

Binkowski D., 2016, Otwarcie drugiego stopnia w twórczości Szkoły Nowojorskiej w świetle teorii Marshalla McLuhana, Kraków: Nomos.

Cage J., 2010, Kompozycja jako proces: niezdeterminowanie, tłum. S. Wieczorek [w:] Kultura dźwięku: teksty o muzyce nowoczesnej, red. Ch. Cox, D. Warner, tłum. J. Kutyła et al., Gdańsk: Słowo/ Obraz Terytoria. 
Demska-Trębacz M., 2005, Czas - przestrzeń - rytm: wykłady lubelskie, Lublin: Polihymnia.

Eco U., 1994, Dzieło otwarte: forma i nieokreśloność w poetykach współczesnych, tłum. J. Gałuszka et al., Warszawa: Czytelnik.

Eco U., 2008, Dzieło otwarte: forma i nieokreśloność w poetykach współczesnych, tłum. L. Eustachiewicz et al., wyd. 3, nowe i popr. przez autora, Warszawa: W.A.B.

Gołąb M., 1987, Dodekafonia: studia nad teoriq i kompozycja pierwszej połowy XX wieku, Bydgoszcz: Redakcja Wydawnictw Pozaprasowych "Pomorze" Pomorskiego Wydawnictwa Prasowego RSW „Prasa - Książka - Ruch”.

Jordan-Szymańska A., 1997, Percepcja formy utworu muzycznego w świetle psychologii poznawczej, „Res Facta Nova”, nr 2 (11).

Popławski M., 2004, Poziom redundancji i rodzaj ekspozycji materiału audiowizualnego a rozpoznawanie informacji telewizyjnych [w:] Psychologiczne aspekty odbioru telewizji 2, red. P. Francuz, Lublin: Towarzystwo Naukowe Katolickiego Uniwersytetu Lubelskiego.

Mianowski J., 2004, Afekt w operach Mozarta i Rossiniego, Poznań: Rhytmos.

Paja-Stach J., 1992, Dzieła otwarte w twórczości kompozytorów XX wieku, Kraków: Uniwersytet Jagielloński.

Rudziński W., 1987, Nauka o rytmie muzycznym, t. 2, Kraków: Polskie Wydawnictwo Muzyczne.

Załuski T., 2000, Umberto Eco: powtórzenie i pozaestetyczny sens awangardy „ „Acta Universitatis Lodziensis. Folia Philosophica", nr 18. 